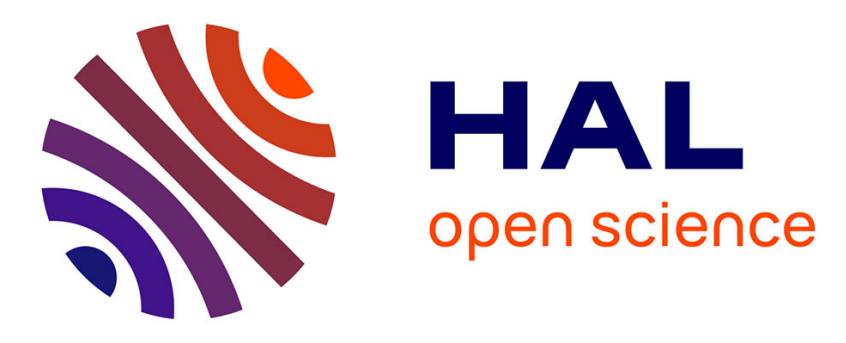

\title{
Effect of histamine on the electrophysiology of the human parietal pleura
}

Kouritas Vk, A. Tsantsaridou, Tepetes K, Tsilimingas N, Gourgoulianis Ki, Molyvdas Pa, Hatzoglou C

\section{- To cite this version:}

Kouritas Vk, A. Tsantsaridou, Tepetes K, Tsilimingas N, Gourgoulianis Ki, et al.. Effect of histamine on the electrophysiology of the human parietal pleura. Molecular and Cellular Endocrinology, 2010, 332 (1-2), pp.271. 10.1016/j.mce.2010.11.003 . hal-00654960

\section{HAL Id: hal-00654960 https://hal.science/hal-00654960}

Submitted on 24 Dec 2011

HAL is a multi-disciplinary open access archive for the deposit and dissemination of scientific research documents, whether they are published or not. The documents may come from teaching and research institutions in France or abroad, or from public or private research centers.
L'archive ouverte pluridisciplinaire HAL, est destinée au dépôt et à la diffusion de documents scientifiques de niveau recherche, publiés ou non, émanant des établissements d'enseignement et de recherche français ou étrangers, des laboratoires publics ou privés. 


\section{Accepted Manuscript}

Title: Effect of histamine on the electrophysiology of the human parietal pleura

Authors: Kouritas VK, Tsantsaridou A, Tepetes K, Tsilimingas N, Gourgoulianis KI, Molyvdas PA, Hatzoglou C

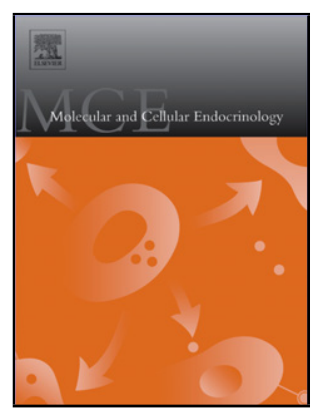

PII:

S0303-7207(10)00531-9

DOI: doi:10.1016/j.mce.2010.11.003

Reference: MCE 7673

To appear in: $\quad$ Molecular and Cellular Endocrinology

Received date: $\quad 18-4-2010$

Revised date: $\quad 7-10-2010$

Accepted date: $\quad$ 7-11-2010

Please cite this article as: VK, K., A, T., K, T., N, T., KI, G., PA, M., C, H., Effect of histamine on the electrophysiology of the human parietal pleura, Molecular and Cellular Endocrinology (2010), doi:10.1016/j.mce.2010.11.003

This is a PDF file of an unedited manuscript that has been accepted for publication. As a service to our customers we are providing this early version of the manuscript. The manuscript will undergo copyediting, typesetting, and review of the resulting proof before it is published in its final form. Please note that during the production process errors may be discovered which could affect the content, and all legal disclaimers that apply to the journal pertain. 


\title{
Title
}

Effect of histamine on the electrophysiology of the human parietal pleura

\section{Authors}

Kouritas $\mathrm{VK}^{1}$, Tsantsaridou $\mathrm{A}^{2}$, Tepetes $\mathrm{K}^{3}$, Tsilimingas $\mathrm{N}^{2}$, Gourgoulianis $\mathrm{KI}^{4}$, Molyvdas $\mathrm{PA}^{1}$, Hatzoglou $\mathrm{C}^{1}$

\author{
Affiliations \\ ${ }^{1}$ Deparment of Physiology, Larissa Medical School, University of Thessaly, Greece \\ ${ }^{2}$ Department of Cardiothoracic Surgery, Larissa University Hospital, Greece \\ ${ }^{3}$ Department of Surgery, Larissa University Hospital, Greece \\ ${ }^{4}$ Department of Thoracic Diseases, Larissa University Hospital, Greece
}

\section{Corresponding Author}

Vasileios K. Kouritas MD, Ph D

Department of Physiology, Medical School of Thessaly

New Buildings, Mezourlo, 41100, PO Box 1400

Tel: +3 $2410685655,+3697440$ 5281, Fax: +3 2410670240

e-mail: kouritas@otenet.gr, vasileios@doctors.net.uk

\section{Conflict of interest}

None declared 


\begin{abstract}
Introduction: Histamine is involved in the pathogenesis of numerous diseases and regulates the permeability of different tissues. The aim of this study is to investigate the effects of histamine on the electrophysiology of human parietal pleura and the underlying mechanisms involved.

Materials and methods: Pleural specimens were obtained from patients subjected to thoracic surgery and were mounted in Ussing chambers. Histamine solutions $(1 \mu \mathrm{M}-$ $1 \mathrm{mM})$ were applied in native and pretreated specimens with dimetindene maleate, cetirizine, ranitidine, amiloride and ouabain. Trans-mesothelial Resistance was determined $\left(\mathrm{R}_{T M}\right)$.

Results: Histamine induced a rapid $\mathrm{R}_{T M}$ increase on the mesothelial $(\mathrm{p}=0.008)$ and a decrease on the interstitial surface $(\mathrm{p}=0.029)$. This effect was dose-dependent and was totally abolished by dimetindene maleate, cetirizine and amiloride and partially by ranitidine and ouabain.

Conclusions: Histamine induces acute electrochemical changes in human pleura mainly via interaction with the $\mathrm{H}_{1}$ and partially with the $\mathrm{H}_{2}$ histamine receptors. It also interferes with trans-cellular permeability and therefore may participate in pleural fluid recycling.
\end{abstract}

\title{
Keywords
}

Histamine; Histamine receptors; Human; Permeability; Pleura; Ussing 


\section{Introduction}

Histamine, following its release by the mast cells, regulates numerous functions in epithelial cells and is involved in the pathogenesis of many diseases (Flynn et al. 2009). These effects are considered to be induced by histamines' interaction with its receptors, namely the $\mathrm{H}_{1}$ and/or $\mathrm{H}_{2}$ histamine receptors (Flynn et al. 2009, Downing et al. 1999).

Furthermore, it is now commonly demonstrated that histamine can acutely regulate trans-cellular transportation either via cellular transporters or via the paracellular pathway, influencing the tight junctions of adjacent cells in various epithelial tissues (Flynn et al. 2009, Zabner et al. 2003, Devalia et al. 2004). The aforementioned effect of histamine is considered to be one of the underlining pathophysiologic mechanisms by which clinical manifestations appear following its release (Flynn et al. 2009, Goldie and Pedersen, 2005).

Despite the fact that histamine is believed to interfere with the formation of pleural exudates (Lo et al. 1995, Kikuchi et al. 1996) an explanation for this effect has not yet been provided.

The aim of the present study is to investigate the effects of histamine on the electrophysiological profile of human parietal pleura and to identify the receptors involved. In addition, we examine the role of cellular ion transporters in this effect. 


\section{Materials and methods}

\subsection{Materials}

Intact sheets of human parietal pleura were obtained from forty (40) patients, who underwent thoracic surgery for lung cancer (via thoracotomy or thoracoscopy). The pleural specimen was obtained from an area distant to the lung tumor. A piece of each dissected specimen was sent for histopathological examination. All specimens included in the study were proven to be free of any disease as per histopathological report. Patients with pleural effusion preoperatively were excluded from the study. After its dissection, the remaining specimen was placed in $K r e b s(K R B)$ solution, preoxygenated at $95 \% \mathrm{O}_{2}-5 \% \mathrm{CO}_{2}$ and cooled at $4^{\circ} \mathrm{C}$, and was transferred to the laboratory within 30 minutes.

The study was approved by the Local Ethics Committee and informed signed consent was obtained from all the patients participating in the study.

\subsection{Methods}

The KRB solution used throughout the whole study was balanced at $\mathrm{pH} 7.45$ and contained $117.5 \mathrm{mM} \mathrm{NaCl}, 1.15 \mathrm{mM} \mathrm{NaH}_{2} \mathrm{PO}_{4}, 24.99 \mathrm{mM} \mathrm{NaHCO}_{3}, 5.65 \mathrm{mM} \mathrm{KCl}$, $1.18 \mathrm{mM} \mathrm{MgSO}_{4}, 2.52 \mathrm{mM} \mathrm{CaCl}_{2}$ and 5.55mM Glucose.

The pleural surface facing the pleural cavity in vivo will be referred to as the mesothelial surface, whereas the surface that faces the chest wall will be referred to as the interstitial surface.

The pleural specimens were mounted as planar sheets of tissue in Ussing type chambers (model DVC-1000, World Precision Instruments, Sarasota, Florida, USA), were bathed in Krebs solution on both sides and perfused continuously with 
$95 \% \mathrm{O}_{2}-5 \% \mathrm{CO}_{2}$ gas mixture, heated to $37^{\circ} \mathrm{C}$, in order to ensure tissue viability

(Hatzoglou et al. 2001, Kouritas et al., 2007, 2008, 2009, 2010).

Following mounting, the pleural specimens were equilibrated for 30 minutes.

Trans-mesothelial Potential Difference (PD) was then measured for 30 minutes, with or without application of current of variable intensity $(0 \pm 400 \mu \mathrm{A})$ (Hatzoglou et al. 2001, Kouritas et al., 2007, 2008, 2009, 2010), constituting the control potential difference. Fifty control experiments were performed.

Following the equilibration period and control measurements, histamine solutions $(1 \mu \mathrm{M}$ to $1 \mathrm{mM}$, Sigma Chemicals Co., USA) were added sequentially on both surfaces in order to investigate their effects on pleural tissue ( $n=7$ experiments for each concentration, $n=7$ experiments for each side). The non-specific histamine receptor antagonist dimetindene maleate (Fenistil ${ }^{\circledR}$, Novartis), the specific and long acting $\mathrm{H}_{1}$ histamine receptor antagonist cetirizine hydrochloride (Zirtek ${ }^{\circledR}$, U.C.B.) and the specific $\mathrm{H}_{2}$ histamine receptor antagonist ranitidine hydrochloride (Zantac ${ }$, GlaxoSmithKline) were used at concentrations ranging from $1 \mu \mathrm{M}$ to $1 \mathrm{mM}$ in order to elucidate the role of histamine receptors in the effect induced by histamine on pleura. The specimens were pretreated with the aforementioned anti-histaminic agents for at least 30 minutes prior to the addition of $10 \mu \mathrm{M}$ histamine $(n=7$ experiments for each drug and $n=7$ experiments for each side). In another group of experiments, specimens were pretreated with the $\mathrm{Na}^{+}$channel blocker amiloride (Sigma Chemical Co., USA, $10 \mu \mathrm{M}$, Kouritas et al., 2008, 2009) and the $\mathrm{Na}^{+} / \mathrm{K}^{+}$pump inhibitor ouabain (Sigma Chemical Co., USA, $10 \mu \mathrm{M}$, Kouritas et al., 2008, 2009) for at least 30 minutes before the addition of $10 \mu \mathrm{M}$ histamine, in order to clarify whether ion cellular transporters take part in the histamine effect on human pleura $(n=7$ experiments for each drug and $n=7$ for each surface). In total, 126 experiments were conducted. 
In order to ensure that the recorded results were due to drug action and not due to mechanical perturbation while emptying and re-filling the chambers, the experiments were conducted using solely Krebs solution (data not shown as no electrical changes in PD were observed). The PD following electrical stimulation with application of current $(0 \pm 400 \mu \mathrm{A})$ was measured $1,5,10,30$ and 60 minutes following the addition of each solution. All solutions were freshly prepared before every experiment, heated to $37^{\circ} \mathrm{C}$ and continuously perfused with $95 \% \mathrm{O}_{2}-5 \% \mathrm{CO}_{2}$ gas mixture.

Trans-mesothelial Resistance $\left(R_{T M}\right)$ was calculated from the PD (Hatzoglou et al. 2001, Kouritas et al., 2007, 2009).

\subsection{Analysis}

Statistical analysis was performed using the statistical package SPSS ver. 10.00 for Windows (Statistical Package for the Social Sciences, SPSS Inc., Chicago, Ill., USA). Data are expressed as Mean $\mathrm{R}_{T M}\left(\Omega \bullet \mathrm{cm}^{2}\right) \pm$ Standard Error of Mean (S.E.) or as net $\mathrm{R}_{T M}$ change $\left(\mathrm{dR}_{T M}\right)$ within $1^{\text {st }}$ minute (calculated by subtracting the mean $\mathrm{R}_{T M}$ from the mean control values for each pair of measurements). Statistical significance was determined by paired $\mathrm{t}$ - test. Comparison among groups was performed by one-way ANOVA (Bonferoni's post hoc). $p$ values less than 0.05 were considered significant. 


\section{Results}

\subsection{Effects of histamine}

The addition of histamine on the mesothelial surface increased the $\mathrm{R}_{T M}$ from $19.23 \pm 0.7 \Omega \cdot \mathrm{cm}^{2}$ to $21.58 \pm 0.7 \Omega \cdot \mathrm{cm}^{2}(p=0.008$ vs. control, fig. 1a) within 5 minutes and remained above the control level thereafter. When added on the interstitial surface, histamine induced a decrease in $\mathrm{R}_{T M}$ from $19.23 \pm 0.7 \Omega \bullet \mathrm{cm}^{2}$ to $17.4 \pm 0.8 \Omega \cdot \mathrm{cm}^{2}(p=0.029$ vs. control, fig. $1 \mathrm{~b}$ ) within 5 minutes and remained at these levels until the end of the experiments. The $\mathrm{R}_{T M}$ change on the mesothelial surface was $2.35 \pm 0.6 \Omega \bullet \mathrm{cm}^{2}$ compared to $1.83 \pm 0.7 \Omega \bullet \mathrm{cm}^{2}$ on the interstitial surface ( $p=0.048$ between the two surfaces). This increase in $\mathrm{R}_{T M}$ was dose-dependent and was greater when higher concentrations of histamine were used. The least effective concentration was $10 \mu \mathrm{M}$ (fig. 2a, 2b).

\subsection{Effect of histamine receptor antagonists}

The addition of dimetindene maleate, cetirizine or ranitidine at concentrations ranging between $1 \mu \mathrm{M}$ and $1 \mathrm{mM}$ had no effect on the $\mathrm{R}_{T M}$ when added on the mesothelial or the interstitial surface of the specimens (fig. 3a, 3b).

\subsection{Effect of anti-histamine agents on the histamine-induced electrochemical changes}

In specimens pretreated with dimetindene maleate the histamine-induced effect was totally inhibited at a lowest concentration of $10 \mu \mathrm{M}$, with the addition of histamine on the mesothelial (from $19.23 \pm 0.7 \Omega \cdot \mathrm{cm}^{2}$ to $19.28 \pm 0.7 \Omega \cdot \mathrm{cm}^{2}, p>0.05$ vs. control and $p=0.018$ vs. histamine, fig. $4 \mathrm{a}$ ) or on the interstitial side (from $19.23 \pm$ 
$0.7 \Omega \cdot \mathrm{cm}^{2}$ to $19.09 \pm 0.8 \Omega \cdot \mathrm{cm}^{2}, p>0.05$ vs. control and $p=0.038$ vs. histamine, fig. 4b) of the specimens.

In tissues pretreated with cetirizine, again, the histamine-induced effect was inhibited at a lowest concentration of $10 \mu \mathrm{M}$, with the addition of histamine on the mesothelial (from $19.23 \pm 0.7 \Omega \cdot \mathrm{cm}^{2}$ to $19.14 \pm 0.7 \Omega \cdot \mathrm{cm}^{2}, p>0.05$ vs. control and $p=0.01$ vs. histamine, fig. 4 a) or on the interstitial surface (from $19.23 \pm 0.7 \Omega \cdot \mathrm{cm}^{2}$ to $19.20 \pm 0.8 \Omega \cdot \mathrm{cm}^{2}, p>0.05$ vs. control and $p=0.01$ vs. histamine, fig. $4 \mathrm{~b}$ ) of the specimens.

In specimens pretreated with ranitidine at a lowest concentration of $10 \mu \mathrm{M}$, histamine induced a weaker effect when compared to the effect observed when added on non-pretreated tissues; ranging from $19.23 \pm 0.7 \Omega \cdot \mathrm{cm}^{2}$ to $20.84 \pm 0.6 \Omega \cdot \mathrm{cm}^{2}$ ( $p=0.001$ vs. control, fig. $4 \mathrm{a}$ ) with the addition of histamine on the mesothelial side and from $19.23 \pm 0.7 \Omega \cdot \mathrm{cm}^{2}$ to $18.22 \pm 0.8 \Omega \cdot \mathrm{cm}^{2}$ ( $p=0.003$ vs. control, fig. $4 \mathrm{~b}$ ) when added on the interstitial surface. This effect had the tendency to reach statistical significance when compared to the effect produced by histamine in non-treated specimens (for mesothelial and interstitial addition vs. histamine $p=0.06$ ).

\subsection{Effect of amiloride and ouabain on the histamine-induced electrochemical} changes

In amiloride pretreated specimens, the histamine-induced effect was inhibited when histamine was added on the mesothelial (from $19.23 \pm 0.7 \Omega \cdot \mathrm{cm}^{2}$ to $18.87 \pm 0.7$ $\Omega \bullet \mathrm{cm}^{2}, p>0.05$ vs. control and $p=0.004$ vs. histamine, fig. 5a) or on the interstitial surface (from $19.23 \pm 0.7 \Omega \cdot \mathrm{cm}^{2}$ to $18.88 \pm 0.7 \Omega \cdot \mathrm{cm}^{2}, p>0.05$ vs. control and $p=0.042$ vs. histamine, fig. $5 \mathrm{~b}$ ) of the specimens. 
In ouabain pretreated specimens, the histamine-induced effect was partially inhibited when histamine was added on the mesothelial (from $19.23 \pm 0.7 \Omega \cdot \mathrm{cm}^{2}$ to $20.17 \pm 0.7 \Omega \cdot \mathrm{cm}^{2}, p=0.055$ vs. control and $p=0.033$ vs. histamine, fig. $\left.5 \mathrm{a}\right)$ or on the interstitial surface (from $19.23 \pm 0.7 \Omega \bullet \mathrm{cm}^{2}$ to $18.48 \pm 0.7 \Omega \bullet \mathrm{cm}^{2}, p=0.048$ vs. control and $p=0.048$ vs. histamine, fig. $5 \mathrm{~b}$ ) of the specimens. 


\section{Discussion}

The main finding of this study is that histamine altered the electrochemical profile of the human parietal pleura and therefore its permeability in a manner dependent on the surface of addition. When added on the mesothelial (intrapleural) surface the $\mathrm{R}_{T M}$ was increased whereas when added on the interstitial (extra-pleural) surface it was decreased. The effect induced on the mesothelial surface was greater than that induced on the interstitial surface. These effects were rapid and dosedependant. Dimetindene maleate and cetirizine totally inhibited the aforementioned effects of histamine suggesting that this electrochemical effect is mediated by the $\mathrm{H}_{1}$ histamine receptors. Ranitidine had a partial inhibitory effect on the histamineinduced electrochemical changes and therefore involvement of the $\mathrm{H}_{2}$ histamine receptors cannot be excluded. Given that amiloride and ouabain hindered the histamine-induced electrochemical changes, involvement of ion cellular transporters in this effect may be assumed.

Histamine is considered to regulate ion transportation influencing mainly the paracellular pathway; it affects the tight junctions of adjacent cells and acutely increases the $\mathrm{Na}^{+}$conductance in airway epithelia (Flynn et al. 2009, Hirace et al. 2001, Zabner et al. 2003). Conversely, histamine interferes with cellular transportation by regulating the ion transporters rather than altering the paracellular permeability and it increases electrical resistance of the human bronchial epithelial cells without increasing the permeability through the tight junctions, (Devalia et al. 1994) an event which was also demonstrated in the porcine proximal colon cells (Ahrens et al. 2003). Histamine also changes the electrochemical profile of fallopian tube cells and ovaries (Downing et al. 1999, 2002) in a dose-dependent manner, while 
it increases the PD and short-circuit current (Isc) of colonic epithelium in mice (Madden et al. 2002), of glomerular epithelial cells (Pavenstädt et al. 1993) and of canine tracheal epithelium (Yamada et al. 1994, Marin et al. 1977). Histamine decreases the PD in nostrils (Yang et al. 2003) and in blood brain barrier (Hurst and Clark, 1998, Butt, 1995) while it increases $\mathrm{Cl}^{-}$conductance and induces $\mathrm{K}^{+}$ permeability and $\mathrm{Ca}^{2+}$ entry via nitric oxide production in vascular cells (Groschner et al. 1994). In pleura, histamine influences permeation through cells, given that, since the pleura is considered 'leaky', the paracellular pathway offers unrestricted passage for solutes (Lai-Fook, 2004, Hatzoglou et al. 2001).

At tissue level, histamine induces a direct increase in vascular permeability (Hirace et al. 2001, Lidegran et al. 1998). The permeability of other tissues such as bronchial, alveolar, lung (Devalia and Davis, 1991, Braude et al. 1984, Vianna and Calixto, 1998) or intestine tissues (Kanwar et al. 1994) may be either increased or decreased by histamine. Therefore, depending on the tissue exposed to histamine, permeability may differ, a fact that may explain the discrepancy noted in our results. We observed that the pleural permeability decreased when histamine was added on the interstitial side (where blood cells, vascular tissue or lipid cells may be present) and increased when added on the mesothelial side.

Results from the present study demonstrate an acute effect of histamine on pleural electrophysiology, observed within minutes from addition. Histamine is known to be involved in the early phases of exudates formation (Kikuchi et al. 1996) but causes late epithelial permeability increase of small intestine cells (Kanwar et al. 1994). The aforementioned electrophysiological studies conducted on other tissues have verified an acute effect of histamine; some studies though have demonstrated 
late histamine-induced electrochemical changes in bronchial epithelial cells, following 6 hours from addition (Devalia et al. 1994).

The involvement of histamine receptors in histamines' effect on permeability of different tissues has been widely demonstrated. $\mathrm{H}_{1}$ receptors seem to play the most important role; in airway epithelia (Flynn et al. 2009, Chan et al. 1987), in vascular epithelia (Flynn et al. 2009), in nostrils (Yang et al. 2003), in Fallopian tubes and ovaries (Downing et al. 1999, 2002) and in human colon (Keely et al. 1995). Nevertheless, $\mathrm{H}_{2}$ receptors may also play a part, as for example in the lung (Braude et al. 1984), in porcine proximal colon (Ahrens et al. 2003) and in rat pleura (Lo et al. 1985). Based on our results, it is evident that the effect of histamine on the electrophysiology of human pleura is mediated mainly via the $\mathrm{H}_{1}$ histamine receptors, whereas $\mathrm{H}_{2}$ receptors seem to be involved partially in this effect. Older antihistaminic agents offering non-specific inhibition of histamine receptors, such as dimetindene maleate, seem also to be able to suppress the histamine-induced electrochemical changes in pleura.

Amiloride-sensitive $\mathrm{Na}^{+}$channels and ouabain-sensitive pumps were previously shown to exist in sheep and human pleura (Hatzoglou et al. 2001, Sarkos et al. 2002) and are considered to interfere with pleural recycling (Hatzoglou et al. 2001, Lai-Fook, 2004). Other hormones, such as insulin, have also been shown previously to obstruct this process by blocking such ion transporters (Kouritas et al. 2010). In a study by Traynor et al. histamine decreased the net $\mathrm{Na}^{+}$absorption in porcine distal colon (Traynor et al. 1993), but amiloride did not inhibit its effect in rat caecum (Homaidan et al. 1997) or in human colon (Keely et al. 1995). Combining the aforementioned with the results from the present study, one can speculate that histamine-induced electrochemical changes in pleura are mediated by ion transporters, 
such as amiloride-sensitive $\mathrm{Na}^{+}$channels and ouabain-sensitive pumps, supporting once again the assumption that histamine interferes with trans-cellular rather than paracellular permeability. Nevertheless, the fact that the paracellular transportation wasn't evaluated in this study constitutes an important limitation.

In the experimental studies in various tissues from different animals mentioned before, histamine was shown to induce observable effects at concentrations of $0.3-3 \mathrm{mM}$. For the inhibitors, concentrations $1 \mu \mathrm{M}-100 \mu \mathrm{M}$ have been reported in the aforementioned studies.

The human tissue used in the present study provides direct information about the pleural behavior of humans after histamine addition. Furthermore, all antihistaminic agents used are commonly used in the treatment of various diseases. Therefore, this study's observations provide realistic information that may in the future be applied in clinical life and treatment. However, the human tissue is difficult to be obtained because of medical - legal issues, consent must be obtained whereas stripping of visceral pleural tissue will lead to air leak. Trying to overcome the aforementioned we have previously shown that sheep pleural tissue appears to be similar and relative to human in terms of pleural electrophysiology (Hatzoglou et al. 2001, Kouritas et al. 2008, 2009, 2010a, 2010b) and its alterations by other hormones such as insulin (Kouritas et al, 2010). This observation is consistent with the fact that various species present similar pleural physiology properties depending on their visceral pleura thickness as is the case for sheep and humans (Lai-Fook, 2004). The effect of histamine in the electrophysiology of sheep visceral and parietal pleura is currently underway.

On clinical basis, histamine is implicated in the inflammatory and allergic reactions, as is the case in pleura, where it causes formation of pleural exudates 
(Kikuchi et al. 1995, Vianna and Calixto, 1998). Our results demonstrate that histamine directly changes the pleural permeability, either when locally released within the pleural cavity (mesothelially), or systematically, when found in the bloodstream (interstitially), providing in this way a plausible explanation for the formation of effusions. Furthermore, commonly used anti-histaminic agents can suppress this effect, a fact which, although at experimental level, may provide new treatment options for exudation or other histamine-mediated adverse effects throughout the body (Tepetes et al. 2009). Finally, it has been suggested that histamine and other inflammatory mediators stimulate sensitive nerve endings positioned on the mesothelial surface of the parietal pleura which participate in respiratory and circulatory control (Jammes et al. 2005, Jammes and Delpierre, 2006). A possible link between the alteration of mesothelial transportation by histamine and the stimulation of such nerve endings needs further clarification.

In conclusion, histamine induces acute electrochemical changes in human parietal pleura seemingly mediated mainly by $\mathrm{H}_{1}$ and in part by $\mathrm{H}_{2}$ histamine receptors. This effect seems to be abolished by ion transporter blockage, suggesting that it elicits alterations in trans-cellular rather than paracellular permeability. Therefore, it may be assumed that histamine directly participates in pleural fluid recycling. 


\section{References}

Ahrens, F., Gäbel, G., Garz, B., Aschenbach, J.R., 2003. Histamine-induced chloride secretion is mediated via H2-receptors in the pig proximal colon. Inflamm. Res. $52,79-85$.

Braude, S., Royston, D., Coe, C., Barnes, P.J., 1984. Histamine increases lung permeability by an H2-receptor mechanism. Lancet. 2, 372-4.

Butt, A.M., 1995. Effect of inflammatory agents on electrical resistance across the blood-brain barrier in pial microvessels of anaesthetized rats. Brain. Res. 696, $145-50$.

Chan, T.B., Eiser, N., Shelton, D., Rees, P.J., 1987. Histamine receptors and pulmonary epithelial permeability. Br. J. Dis. Chest. 81, 260-7.

Devalia, J.L., Davies, R.J., 1991. Human nasal and bronchial epithelial cells in culture: an overview of their characteristics and function. Allergy. Proc. 12, 71-9.

Devalia, J.L., Godfrey, R.W., Sapsford, R.J., Severs, N.J., Jeffery, P.K., Davies, R.J., 1994. No effect of histamine on human bronchial epithelial cell permeability and tight junctional integrity in vitro. Eur. Respir. J. 7, 1958-1965.

Downing, S.J., Chambers, E.L., Maguiness, S.D., Watson, A., Leese, H.J., 1999. Effect of Inflammatory Mediators on the Electrophysiology of the Human Oviduct. Biol. Reproduct. 61, 657-664.

Downing, S.J., Tay, J.I., Maguiness, S.D., Watson, A., Leese, H.J., 2002. Effect of inflammatory mediators on the physiology of the human Fallopian tube. Hum. Fertil. (Camb). 5, 54-60. 
Flynn, A.N., Itani, O.A., Moninger, T.O., Welsh, M.J., 2009. Acute regulation of tight junction ion selectivity in human airway epithelia. Proc. Natl. Acad. Sci. U. S. A. $106,3591-6$.

Goldie, R.G., Pedersen, K.E., 1995. Mechanisms of increased airway microvascular permeability: role in airway inflammation and obstruction. Clin. Exp. Pharmacol. Physiol. 22, 387-96.

Groschner, K., Graier, W.F., Kukovetz, W.R., 1994. Histamine induces K+, Ca2+, and $\mathrm{Cl}$ - currents in human vascular endothelial cells. Role of ionic currents in stimulation of nitric oxide biosynthesis. Circ. Res. 75, 304-14.

Hatzoglou, C.H., Gourgoulianis, K.I., Molyvdas, P.A., 2001 Effects of SNP, ouabain and amiloride on electrical potential profile of isolated sheep pleura. J. Appl. Physiol. 90, $1565-1569$.

Hirase, T., Kawashima, S., Wong, E.Y.M., Ueyama, T., Rikitake, Y., Tsukita, S., Yokoyama, M., Staddon, J.M., 2001. Regulation of Tight Junction Permeability and Occludin Phosphorylation by RhoA-p160ROCK-dependent and -independent Mechanisms. J. Biol. Chem. 276, 10423-10431.

Homaidan, F.R., Tripodi, J., Zhao, L., Burakoff, R., 1997. Regulation of ion transport by histamine in mouse cecum. Eur. J. Pharmacol. 331, 199-204.

Hurst, R.D., Clark, J.B., 1998. Alterations in transendothelial electrical resistance by vasoactive agonists and cyclic AMP in a blood-brain barrier model system. Neurochem. Res. 23, 149-54.

Jammes, Y., Delpierre, S., 2006. Respiratory and circulatory effects of parietal pleural afferent stimulation in rabbits. J. Appl. Physiol. 100, 1539-46.

Jammes, Y., Trousse, D., Delpierre, S., 2005. Identification and properties of parietal pleural afferents in rabbits. J. Physiol. 567, 641-50. 
Kanwar, S., Wallace, J.L., Befus, D., Kubes, P., 1994. Nitric oxide synthesis inhibition increases epithelial permeability via mast cells. Am. J. Physiol. 266, G222-9.

Keely, S.J., Stack, W.A., O'Donoghue, D.P., Baird, A.W., 1995. Regulation of ion transport by histamine in human colon. Eur. J. Pharmacol. 279, 203-9.

Kikuchi, M., Tsuzurahara, K., Suzuki, T., Yato, N., Naito, K., 1996. Involvement of leukotrienes in allergic pleurisy in actively sensitized rats: inhibition by the lipoxygenase inhibitor $\mathrm{T}-0757$ of the increase in vascular permeability and leukotriene E4 production. Inflamm. Res. 45, 192-7.

Kouritas, V.K., Hatzoglou, C., Foroulis, C.N., Gourgoulianis, K.I., 2008. Human parietal pleura present electrophysiology variations according to location in pleural cavity. ICVTS. 7, 544-7.

Kouritas, V.K., Hatzoglou, C., Foroulis, C.N., Hevas, A., Gourgoulianis, K.I., Molyvdas, P.A., 2007. Low glucose level and low pH alter the electrochemical function of human parietal pleura. Eur. Respir. J. 30, 354 - 357.

Kouritas, V.K., Hatzoglou, C., Gourgoulianis, K.I., Molyvdas, P.A., 2009. Pleural electrophysiology variations according to location in pleural cavity. ICVTS. 9, $391-4$.

Kouritas, V.K., Hatzoglou, C.H., Ioannou, M., Gourgoulianis, K.I., Molyvdas, P.A., 2010a. Insulin alters the permeability of sheep pleura. Exp. Clin. Endocrinol. Diabetes. 118, 304-9.

Kouritas, V.K., Ioannou, M., Foroulis, C.N., Desimonas, N., Evaggelopoulos, K., Gourgoulianis, K.I., Molyvdas, P.A., Hatzoglou, C. 2010b. Insulin-induced electrophysiology changes in human pleura are mediated via its receptor. Exp. Diabetes. Res. 853176, Article in press. 
Lai - Fook, S.J., 2004. Pleural mechanics and fluid exchange. Physiol. Rev. 84, 385 410.

Lidegran, M., Domeij, S., Carlsöö, B., Dahlqvist, A., 1998. Edema formation in the rat larynx. Cell. Tissue. Res. 292, 367-75.

Lo, T.N., WoldeMussie, E., Wilson, N., Wu, D., Beaven, M.A., 1985. Inflammatory response induced by intrapleural injection of antiserum to $\operatorname{IgE}$ in rat. An evaluation of the role of histamine. Biochem. Pharmacol. 34, 3901-7.

Madden, K.B., Whitman, L., Sullivan, C., Gause, W.C., Urban, J.F. Jr., Katona, I.M., Finkelman, F.D., Shea-Donohue, T., 2002. Role of STAT6 and mast cells in IL-4and IL-13-induced alterations in murine intestinal epithelial cell function. J. Immunol. 169, 4417-22.

Marin, M.G., Davis, B., Nadel, J.A., 1977. Effect of histamine on electrical and ion transport properties of tracheal epithelium. J. Appl. Physiol. 42, 735-8.

Pavenstädt, H., Bengen, F., Späth, M., Schollmeyer, P., Greger, R., 1993. Effect of bradykinin and histamine on the membrane voltage, ion conductances and ion channels of human glomerular epithelial cells (hGEC) in culture. Pflugers. Arch. 424, 137-44.

Sarkos, S., Hatzoglou, C.H., Dahabre, J., Gourgoulianis, K.I., Molyvdas, P.A., 2002. Effect of amiloride in human and sheep parietal pleura. Respir. Physiol. 132, 233237.

Tepetes, K., Asprodini, E.K., Christodoulidis, G., Spyridakis, M., Kouvaras, E., Hatzitheofilou, K., 2009. Prevention of postoperative adhesion formation by individual and combined administration of 4 per cent icodextrin and dimetindene maleate. Br. J. Surg. 96, 1476-1483. 
Traynor, T.R., Brown, D.R., O'Grady, S.M., 1993. Effects of inflammatory mediators on electrolyte transport across the porcine distal colon epithelium. J. Pharmacol. Exp. Ther. 264, 61-6.

Vianna, R.M., Calixto, J.B., 1998. Characterization of the receptor and the mechanisms underlying the inflammatory response induced by des-Arg9-BK in mouse pleurisy. Br. J. Pharmacol. 123, 281-91.

Yamada, K., Shimura, S., Satoh, M., Sasaki, T., Yamauchi, K., Takishima, T., 1994. HMT regulates histamine-induced $\mathrm{Cl}$ - secretion across the canine tracheal epithelium. Respir. Physiol. 97, 105-9.

Yang, T.Q., Takeuchi, K., Hayashi, S., Majima, Y., 2003. Effect of histamine on the permeability of the nasal mucosa in vivo. Acta. Otolaryngol. 123, 401-5.

Zabner, J., Winter, M., Ashbourne Excoffon, K.J.D., Stoltz, D., Ries, D., Shasby, S., Shasby, M., 2003. Histamine alters E-cadherin cell adhesion to increase human airway epithelial permeability. J. Appl. Physiol. 95, 394-401. 


\section{Figure Legends}

Figure 1: Effect of HISTAMINE $10 \mu \mathrm{M}$ on the Trans-mesothelial Resistance $\left(\mathrm{R}_{T M}\right)$ when added on the mesothelial (a) and interstitial (b) surface of human parietal pleura, by time. Values are expressed as Mean Trans-mesothelial Resistance $\mathrm{R}_{T M}\left(\Omega \cdot \mathrm{cm}^{2}\right) \pm$ Standard Error of Mean; $n=7$ experiments. ${ }^{*} p<0.05$ vs. Control

Figure 2: Net Trans-mesothelial Resistance change after addition of different HISTAMINE solutions at different concentrations $(1 \mu \mathrm{M}$ to $1 \mathrm{mM})$ on the mesothelial (a) and interstitial (b) surface of human parietal pleura. The increase was significant for concentrations $\geq 10 \mu \mathrm{M}$. Values are expressed as net change of Trans-mesothelial Resistance $\mathrm{R}_{T M}\left(\Omega \bullet \mathrm{cm}^{2}\right) \pm$ Standard Error of Mean of $n=7$ for each set of experiments. ${ }^{*} p<0.05$ above zero RTM change level.

Figure 3: Effect of DIMETINDENE MALEATE $(10 \mu \mathrm{M})$, CETIRIZINE $(10 \mu \mathrm{M})$ and RANITIDINE $(10 \mu \mathrm{M})$ on the Trans-mesothelial Resistance $\left(\mathrm{R}_{T M}\right)$ when added on the mesothelial (a) and interstitial (b) surface of human parietal pleura. Values are expressed as Mean Trans-mesothelial Resistance $\mathrm{R}_{T M}\left(\Omega \bullet \mathrm{cm}^{2}\right) \pm$ Standard Error of Mean of $n=7$ experiments.

Figure 4: Effect of HISTAMINE $(10 \mu \mathrm{M})$ in pre-treated tissues with DIMETINDENE MALEATE $(10 \mu \mathrm{M})$, CETIRIZINE $(10 \mu \mathrm{M})$ and RANITIDINE $(10 \mu \mathrm{M})$ when added on the mesothelial (a) and interstitial (b) surface of human parietal pleura. Values are expressed as Mean Trans-mesothelial Resistance $\mathrm{R}_{T M}\left(\Omega \bullet \mathrm{cm}^{2}\right) \pm$ Standard Error of Mean of $n=7$ experiments. ${ }^{*} p<0.05$ vs. control, $\# p<0.05$ vs. histamine 
Figure 5: Effect of HISTAMINE $(10 \mu \mathrm{M})$ in pre-treated tissues with AMILORIDE $(10 \mu \mathrm{M})$ and OUABAIN $(10 \mu \mathrm{M})$ when added on the mesothelial (a) and interstitial (b) surface of human parietal pleura. Values are expressed as Mean Trans-mesothelial Resistance $\mathrm{R}_{T M}\left(\Omega \bullet \mathrm{cm}^{2}\right) \pm$ Standard Error of Mean of $n=7$ experiments. ${ }^{*} p<0.05$ vs. control, $\# p<0.05$ vs. histamine 

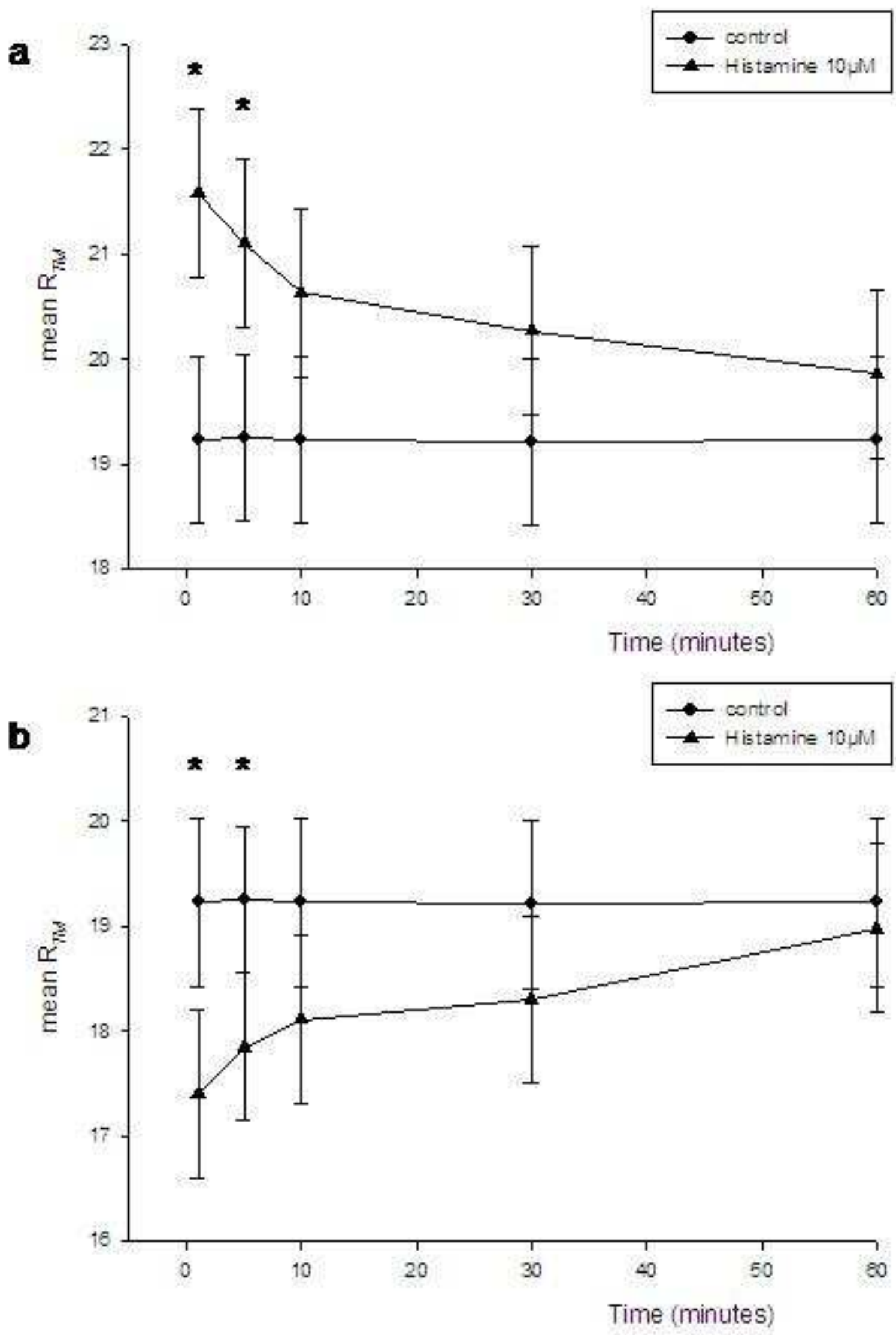

Figure 1 

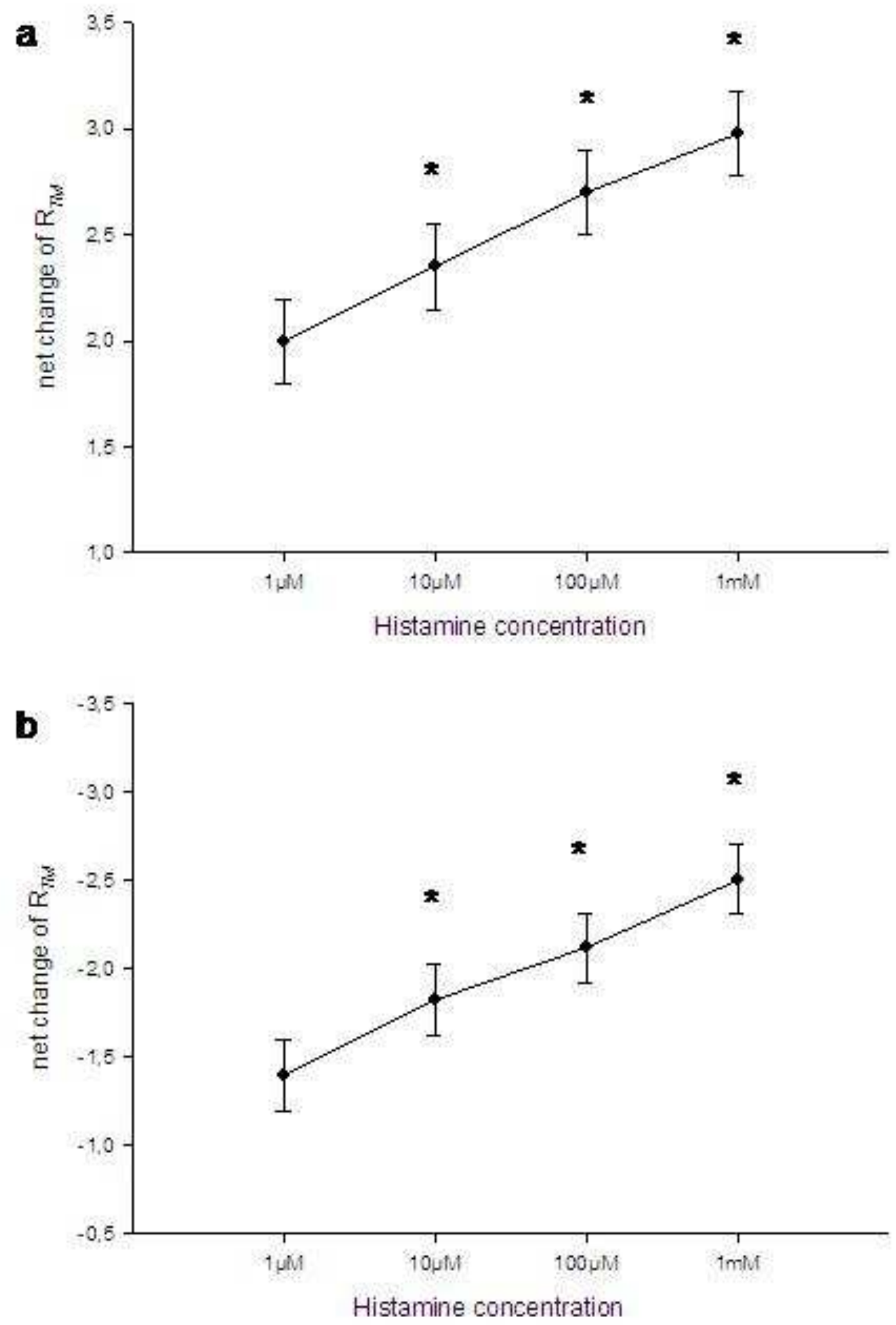

Figme 2 

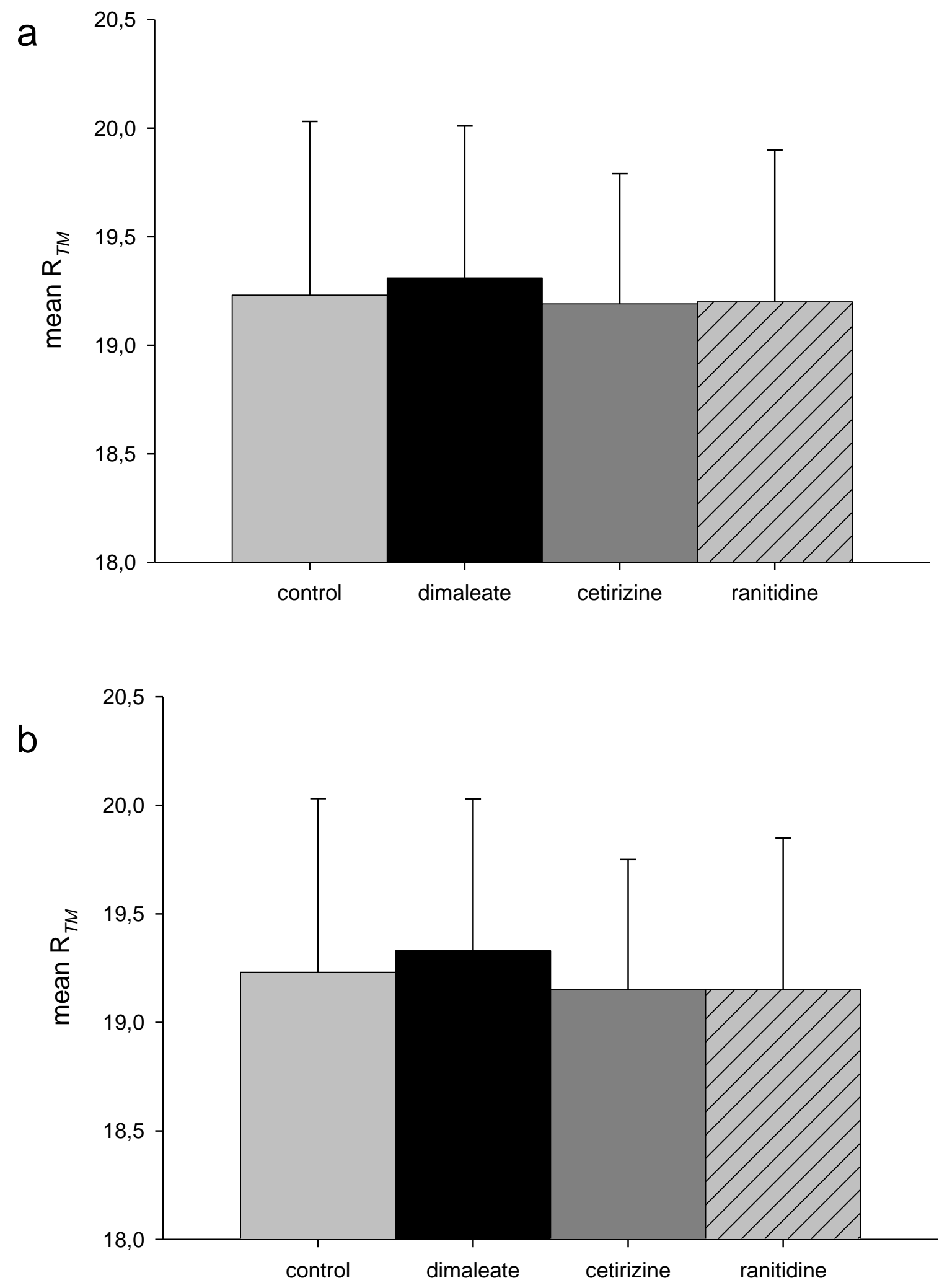

Figure 3 

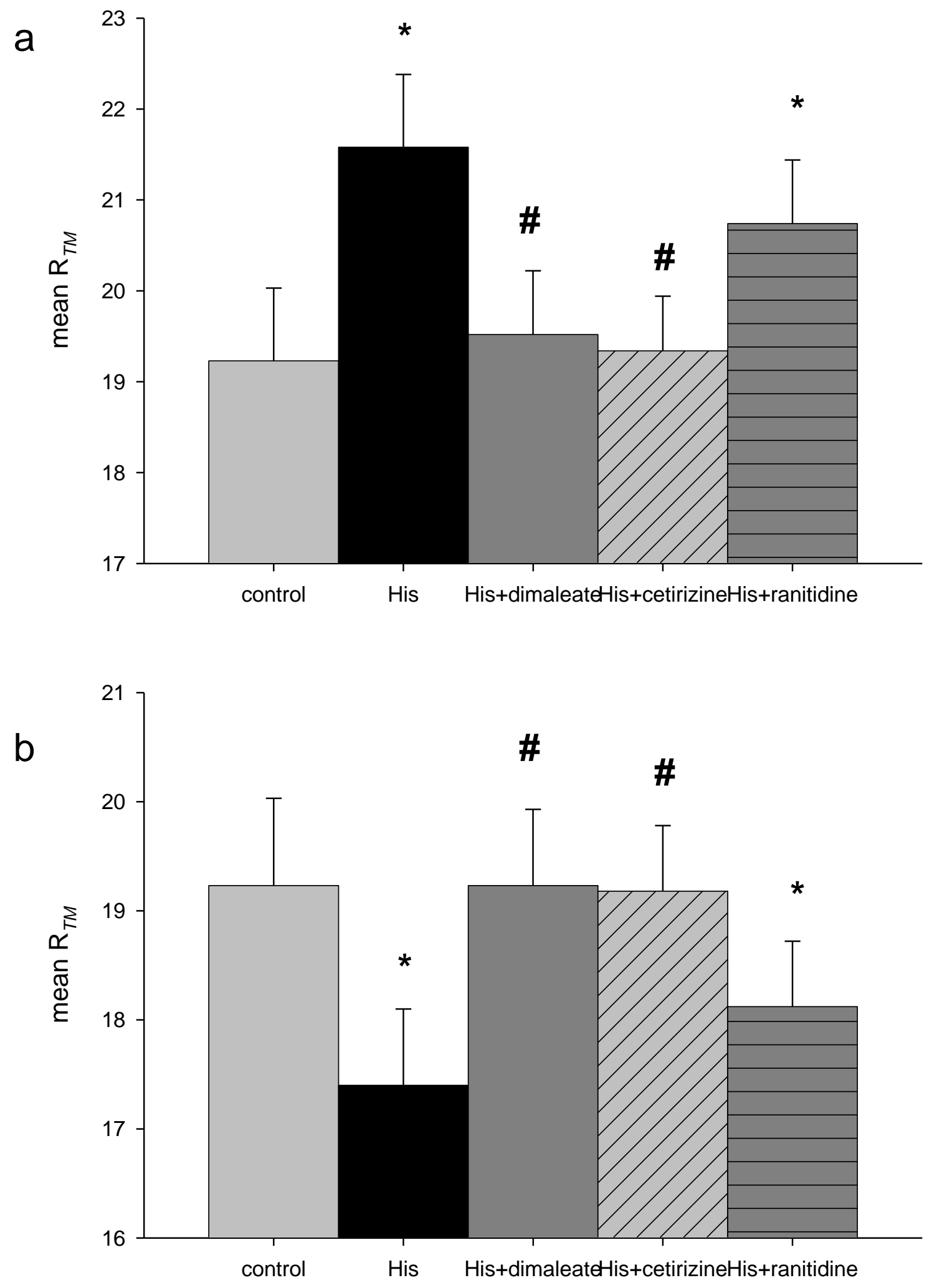

Figure 4 

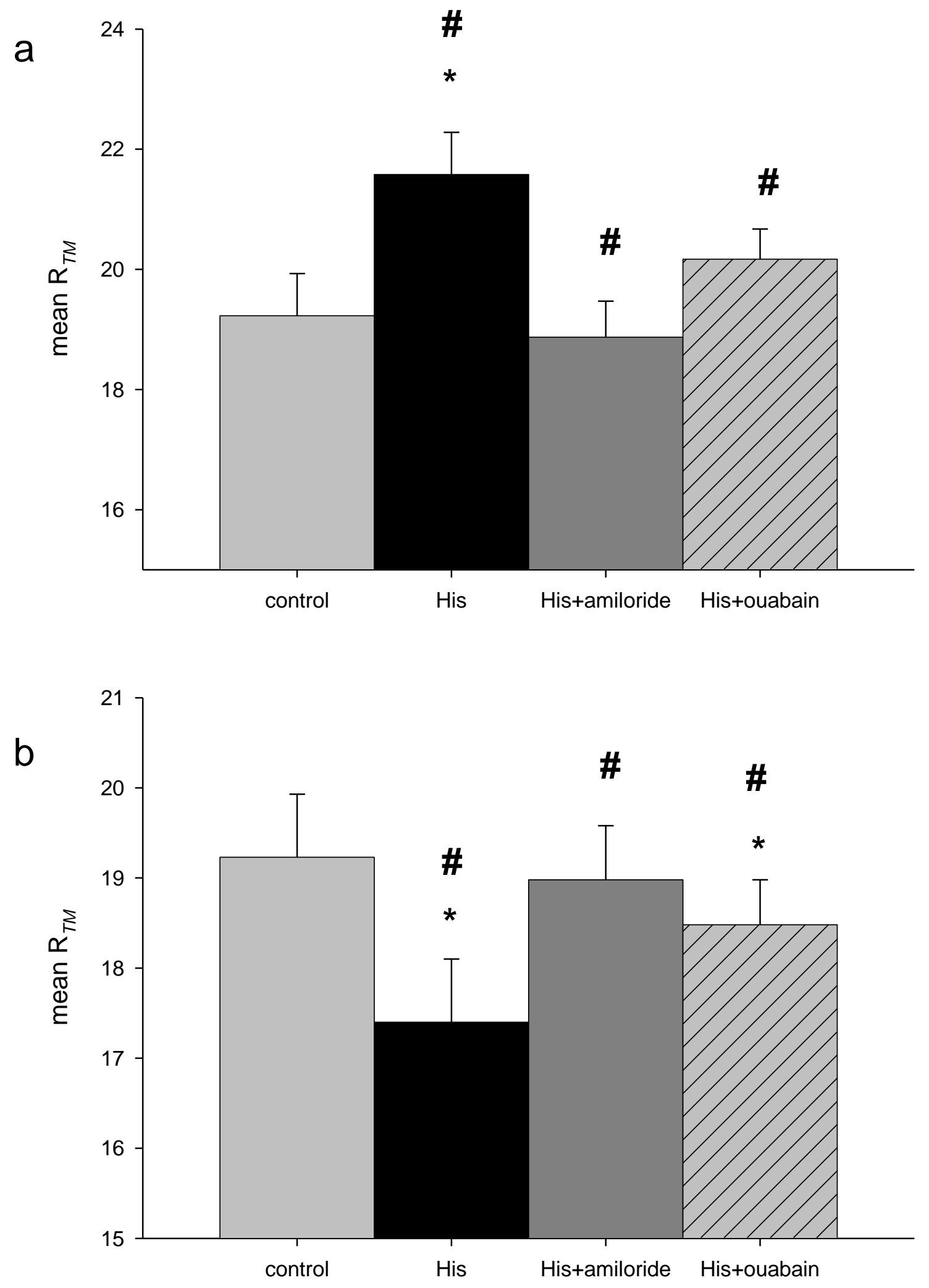

Figure 5 